\title{
GASTRIC LAVAGE FOR DIETARY STUDIES OF SMALL FISHES: EFFICIENCY, SURVIVAL AND APPLICABILITY
}

\author{
Raul Rennó BRAGA ${ }^{1,2 *}$, Vanessa Maria RIBEIRO ${ }^{1,2}$, Hugo BORNATOWSKI ${ }^{1,2}$, \\ Vinicius ABILHOA ${ }^{2}$, and Jean Ricardo Simões VITULE ${ }^{1,2}$ \\ ${ }^{1}$ Federal University of Paraná, Curitiba, Brazil \\ ${ }^{2}$ Research Group on Ichthyofauna, Natural History Museum Capão da Imbuia, Curitiba, Brazil
}

Braga R.R., Ribeiro V.M., Bornatowski H., Abilhoa V., Vitule J.R.S. 2017. Gastric lavage for dietary studies of small fishes: Efficiency, survival and applicability. Acta Ichthyol. Piscat. 47 (1): 97-100.

\begin{abstract}
Studies on feeding ecology provide information of great importance to the understanding of aquatic ecosystems. However, these studies usually require the sacrifice of animals. In view of this problem, the presently reported study aims to evaluate the effectiveness and applicability of the gastric lavage method for small catfishes. There was no mortality recorded for the 80 specimens of Rhamdia quelen (Quoy et Gaimard, 1824) and after recovery from anaesthesia all fish presented a normal swimming pattern. With the gastric lavage method we were able to retrieve $71.4 \%$ of the stomach contents of 34 specimens of Pimelodella pappenheimi Ahl, 1925. These results serve as a stimulus for studies prioritizing non-lethal techniques. These methods would ensure greater knowledge about ecology and conservation of smaller fishes, especially to populations of small and rare species that are the most endangered in freshwater systems.
\end{abstract}

Keywords: feeding ecology, non-lethal techniques, Siluriformes, conservation, Heptapteridae

Fish stomach content analysis provides information of great importance to our understanding of aquatic ecosystems (Braga et al. 2012). Studies of fish feeding ecology usually require sacrificing a great number of individuals (Petridis and O'Hara 1988, Barnett et al. 2010). This can inflict severe effects on natural populations since it can reduce genetic diversity to deleterious levels (Kamler and Pope 2001), alter population structure (Light et al. 1983), and even create a bad impression of fisheries science to the society as a whole (Hakala and Johnson 2004). The situation is even worse when dealing with a species or a population that is already threatened (Shuman and Peters 2007). In these cases, because of the legal protections involved, it becomes necessary to use non-lethal methodologies (Grohs et al. 2009). Non-lethal methods are also of great importance in experimental studies in which it is necessary to capture, manipulate, and recapture the same individual (Baxter et al. 2007). In addition, there are also ethical considerations involved and we must reduce the number of animals used through appropriate experimental planning and statistical techniques (Russel and Burch 1959, Leary 2013).

The gastric lavage (GL) method using a syringe to inject water through the mouth and oesophagus is the most promising one for small sized species (Meehan and Miller 1978, Hyslop 1980, Kamler and Pope 2001). However, many risks that may be associated with this method were not properly considered and/or tested, such as stress, prolonged handling time, tissue damage in the oesophagus and stomach (Shuman and Peters 2007), as well as survival and longevity after release back into the natural environment. Also the efficiency of GL can be affected by the stomach shape, the size of the mouth, and food items of particular fish species (Kamler and Pope 2001, Waters et al. 2004), thus, reliability should be established for studied population or at least for typical model species of a larger group of similar species or higher taxa.

The freshwater Neotropical ichthyofauna is marked by small-sized species, especially in streams with high number of rare, endemics or small size populations (Castro 1999, Abilhoa et al. 2011). These characteristics are serious reasons to use non-lethal methods of stomach (gut) content sampling. Although a considerable number of non-lethal methods for obtaining stomach contents are known (Kamler and Pope 2001, Manko 2016) and should be appropriate and suitable for the Neotropical fish fauna, there is no record of their use with Neotropical stream fishes. At the same time a large fraction of these species remains unknown in relation to their basic biological and ecological aspects (Vari and Malabarba 1998). This situation extends to members of the family Heptapteridae, which is the most represented family within the 
Siluriformes in small rivers and streams of this region (de Pinna 1998, Bockmann and Guazzelli 2003) and also includes many small species represented in national and regional red lists of threatened species. Therefore, the representatives of these Neotropical fish family are appropriate model species to evaluate the effectiveness and mortality of syringe-based GL.

The goal of the presently reported study was to evaluate the effectiveness and applicability of the GL method for small Neotropical stream fishes belonging to the order Siluriformes. To achieve this goal, we addressed the following two questions: Is the method efficient in accessing stomach contents? Does the GL affect the survival rate of individuals subjected to the method?

The efficiency experiments were conducted with Pimelodella pappenheimi Ahl, 1925 and the mortality tests were conducted with Rhamdia quelen (Quoy et Gaimard, 1824). Both were chosen as model for the vast majority of small catfishes, especially in terms of morphological and behavioural patterns. Pimelodella pappenheimi specimens used in the experiment were collected from the Guaraguaçu River, southern Brazil $\left(25^{\circ} 40^{\prime} 22.87^{\prime \prime} \mathrm{S}, 48^{\circ} 30^{\prime} 45.79^{\prime \prime} \mathrm{W}\right)$ using the hook and line method. Rhamdia quelen specimens were purchased from an aquaculture facility.

Before GL, fish were anesthetized in a clove oil solution (Cunha and Rosa 2006), containing 10\% clove oil, $40 \%$ alcohol ( $70 \%$ solution), and $50 \%$ of water. Fish were considered sedated if they showed slow opercular movements, loss of balance and no reaction to contact stimulus. After the anaesthesia, fish were measured (total and standard length to the nearest $\mathrm{mm}$ ), weighed (to the nearest $\mathrm{g}$ ) and then subjected to GL.

Gastric lavage was conducted using a siliconized plastic catheter with round edges, $380 \mathrm{~mm}$ in length, with a 2-mm external diameter and a 1-mm internal diameter attached to a $60 \mathrm{~cm}^{3}$ syringe. With the thumb positioned on the ventral portion of the fish it was possible to feel when the catheter reached the stomach. With the catheter inserted water was injected slowly and continually. The fish was positioned with the dorsal side down at about a $45^{\circ}$ angle, and the ventral surface of the fish was massaged to facilitate regurgitation. The retrieved stomach contents were collected in a plastic bottle containing a $10 \%$ formaldehyde solution. A minimum of 30 and a maximum of $60 \mathrm{~cm}^{3}$ of water were used for the GL. Food items seen to be stuck in the oral cavity were removed using tweezers. After GL, fish were placed in a 2-L bowl of water and their recovery monitored. The time for administering anaesthesia, GL, and recovery and the time for the total procedure were recorded.

Efficiency experiments were conducted in the field. Pimelodella pappenheimi were captured and stored in a plastic box containing $40 \mathrm{~L}$ of water equipped with an aerator to prevent oxygen depletion. All fish were subjected to GL and the retrieved stomach contents were stored in a formaldehyde solution (10\%). In the laboratory, the recovered stomach contents were filtered onto a $45 \mu \mathrm{m}$ membrane filter using a vacuum pump to separate food items from the formaldehyde solution for later weighing of the contents $(0.001 \mathrm{~g})$. All fish were dissected to see if there were any remaining food items not retrieved by the GL. The efficiency was calculated as the percentage of recovered items (weight) during GL in relation to the total ingested by the fish (remaining items in the stomach added to the recovered by the GL) (Hakala and Johnson 2004).

Survival experiments were conducted in the laboratory. A total of eight plastic boxes containing $20 \mathrm{~L}$ of water were used as aquaria for the experiment. These were divided into four controls (subjected to the entire procedure except for GL) and four treatments (subjected to GL). The water temperature was controlled and maintained at $25^{\circ} \mathrm{C}$. We used ten specimens of Rhamdia quelen per aquarium. The experiments began after a one-week period of acclimatization. Mortality was monitored once a day for one week.

Pearson's correlation coefficient was used to access the relation between time of anaesthesia and total length. Statistical analysis of survival rates was conducted using a Mann-Whitney test, where the mortality rate ( $n$ of specimens in the aquarium / $n$ of deaths at the end of one week), was compared between treatments and controls.

A total of 34 specimens of Pimelodella pappenheimi were used in the efficiency test. The mean total length ( \pm standard deviation) was $122 \pm 35.5 \mathrm{~mm}$ and the mean total weight $( \pm \mathrm{SD})$ was $18.5 \pm 16.9 \mathrm{~g}$. The mean time of anaesthesia was $68 \pm 16.5 \mathrm{~s}$ and of recovery was $270 \pm 99$ s. There was no correlation between time of anaesthesia and total length $(r=0.47, p=0.06)$. The GL method had a mean duration of $174.5 \pm 53.9 \mathrm{~s}$. There was no mortality recorded during GL, and after recovery from anaesthesia all fish presented a normal swimming pattern. With the GL method we were able to retrieve $71.4 \%$ of the stomach contents.

There was no mortality recorded for the 80 specimens of Rhamdia quelen used in the experiment. The mean total length was $76 \pm 10 \mathrm{~mm}$ and the mean total weight was 3.7 $\pm 1.44 \mathrm{~g}$. The mean time of anaesthesia was $52 \pm 15.7 \mathrm{~s}$ and of recovery was $420 \pm 360 \mathrm{~s}$. There was no correlation between time of anaesthesia and total length $(r=0.16, p$ $=0.15)$.

When analysing the method's efficiency with Pimelodella pappenheimi it is clear that the GL is reasonably efficient. Tests with the blue catfish, Ictalurus furcatus (Valenciennes, 1840), and the flathead catfish, Pylodictis olivaris (Rafinesque, 1818), showed greater than $95 \%$ efficiency at removing stomach contents (Waters et al. 2004). The internal morphology of these species may be responsible for this high efficiency. They present a wide oral cavity and oesophagus that facilitates the insertion and simultaneous retrieval of food items. Additionally, their ventral sides do not have bone structures on the stomach portion, which allows the researcher to feel the catheter when it reaches the stomach cavity and to feel remaining large food items.

The required equipment for the GL had a low cost, under US\$ 30.00, and all equipment used can be purchased in drugstores, hospital equipment stores, and aquarium 
stores. It is simple to assemble and is easily transported to any location, which seems to be an advantage over the methods of Culp et al. (1988) and Light et al. (1983) when collecting fish in remote places. Two people can easily operate the equipment and conduct all the sampling and it takes no more than three minutes to extract the stomach contents of each fish.

Another important feature is that, contrary to techniques that utilize electric water pumps, the use of a syringe allows the researcher to interrupt the water flow when a large food item gets stuck in the animal's throat, preserving the fish's integrity and life. It is also easily adaptable to a wide range of fish sizes, only requiring an exchange of the catheter for a wider one. On the other hand, it is possible that insertion of the catheter pushes some of the ingested items to the intestinal portion, making them impossible to be retrieved.

The survival of $100 \%$ of the tested Rhamdia quelen suggests that the GL method is safe for use with very similar, endangered, catfish species. In addition, when testing the efficiency of the method with P. pappenheimi, no deaths were recorded during or after the GL. These results are consistent with several other studies using different species (Light et al. 1983, Hakala and Johnson 2004, Wanner 2006, Shuman and Peters 2007).

Considering the high efficiency and low mortality for small Siluriformes, GL seems to be a promising method. In Brazil, for example, there are 35 threatened Siluriformes on the national red list, six of which belong to the family Heptapteridae (see Rosa and Lima 2008). Collecting and sacrificing a great number of fish is, in fact, a questionable practice, considering the variety of non-lethal methods available today. Despite the fact that for the past 80 years (since White 1930) there have been several non-lethal methods available for the analysis of gut contents, they are rarely used. Among important factors when choosing the method are: the size of specimens, the nature and size of ingested items, the budget and the number of people needed to operate the equipment (Baker and Fraser 1976, Kamler and Pope 2001). Logistic and operational considerations are also important; these include the time available for field trials of fish and the availability of a suitable place to carry out the collection of gut contents.

We believe that this study will serve as a stimulus for new and innovative studies concerning such an important, although underexplored theme. This method and ideas would ensure greater knowledge about ecology and conservation of fishes, especially the rare and endangered ones.

\section{ACKNOWLEDGMENTS}

We thank Dr James Nienow for English language revision; the National Council for Scientific and Technological Development $(\mathrm{CNPq})$ for research grants to JRSV, the Coordination for the Improvement of Higher Education Personnel (CAPES) for scholarship to RRB, VR, and HB.

\section{REFERENCES}

Abilhoa V., Braga R.R., Bornatowski H., Vitule J.R.S. 2011. Fishes of the Atlantic rain forest streams: ecological patterns and conservation. Pp. 259-282. In: Grillo O., Venora G. (eds.) Changing diversity in changing environment. InTech, Rijeka, Croatia.

Baker A.M., Fraser D.F. 1976. A method for securing the gut contents of small, live fish. Transactions of the American Fisheries Society 105 (4): 520-522. DOI: $10.1577 / 1548-8659$ (1976)105<520:AMFSTG $>2.0 . C O ; 2$

Barnett A., Redd K.S., Frusher S.D., Stevens J.D., Semmens J.M. 2010. Non-lethal method to obtain stomach samples from a large marine predator and the use of DNA analysis to improve dietary information. Journal of Experimental Marine Biology and Ecology 393 (1-2): 188-192.

DOI: $10.1016 /$ j.jembe.2010.07.022

Baxter C.V., Fausch K.D., Murakami M., Chapman P.L. 2007. Invading rainbow trout usurp a terrestrial prey subsidy from native charr and reduce their growth and abundance. Oecologia 153 (2): 461-470.

DOI: $10.1007 / \mathrm{s} 00442-007-0743-\mathrm{X}$

Bockmann F.A., Guazzelli G. 2003. Family Heptapteridae. Pp. 406-431. In: Reis R.E., Kullander S.O., Ferraris C.J.jr. (eds.) Check list of the freshwater fishes of South and Central America. EdiPUCRS, Porto Alegre, Brazil.

Braga R.R., Bornatowski H., Vitule J.R.S. 2012. Feeding ecology of fishes: An overview of worldwide publications. Reviews in Fish Biology and Fisheries 22 (4): 915-929.

DOI: $10.1007 / \mathrm{s} 11160-012-9273-7$

Castro R.M.C. 1999. Evolução da ictiofauna de riachos sul-americanos: padrões gerais e possíveis processos causais. [Evolution of the ichthyofauna of South American streams: General patterns and possible causal processes.] Pp. 139-155. In: Caramaschi E.P., Mazzoni R., Bizerril C.R.S.F., Peres-Neto P.R. (eds.) Ecologia de peixes de riachos: Estado atual e perspectivas. [Ecology of brook fish: Current state and perspectives.] Série Oecologia Brasiliensis/PPGEUFRJ, Rio de Janeiro, Brazil. [In Portuguese.]

Culp J.M., Boyd I., Glozier N.E. 1988. An improved method for obtaining gut contents from small, live fishes by anal and stomach flushing. Copeia 1988 (4): 1079-1082.

DOI: $10.2307 / 1445740$

Cunha F.E.A., Rosa I.L. 2006. Anaesthetic effects of clove oil on seven species of tropical reef teleosts. Journal of Fish Biology 69 (5): 1504-1512. DOI: 10.1111/j.1095-8649.2006.01213.x

de Pinna M.C.C. 1998. Phylogenetic relationships of Neotropical Siluriformes: Historical overview and synthesis of hypothesis. Pp. 279-330. In: Malabarba L.R., Reis R.E., Vari R.P., Lucena Z.M.S., Lucena C.A.S. (eds.) Phylogeny and classification of Neotropical fishes. EdiPUCRS, Porto Alegre, Brazil.

Grohs K.L., Klumb R.A., Chipps S.R., Wanner G.A. 2009. Ontogenetic patterns in prey use by 
pallid sturgeon in the Missouri River, South Dakota and Nebraska. Journal of Applied Ichthyology 25 (Suppl. 2): 48-53.

DOI: $10.1111 /$ j.1439-0426.2009.01279.x

Hakala J.P., Johnson F.D. 2004. Evaluation of a gastric lavage method for use on largemouth bass. North American Journal of Fisheries Management 24 (4): 1398-1403.

DOI: $10.1577 / \mathrm{M} 03-092.1$

Hyslop E.J. 1980. Stomach contents analysis - a review of methods and their application. Journal of Fish Biology 17 (4): 411-429. DOI: $10.1111 /$ j.1095-8649.1980.tb02775.x

Kamler J.F., Pope K.L. 2001. Nonlethal methods of examining fish stomach contents. Reviews in Fisheries Science 9 (1): 1-11. DOI: $10.1080 / 20016491101663$

Leary S., Underwood W., Anthony R., Cartner S., Corey D., Grandin T., Greenacre C., GwaltneyBrant S., McCrackin M.A., Meyer R., Miller D., Shearer J., Yanong R., Golab G.C., Patterson-Kane E. 2013. AVMA Guidelines for the euthanasia of animals: 2013 Edition. American Veterinary Medical Association.

Light R.W., Adler P.H., Arnold D.E. 1983. Evaluation of gastric lavage for stomach analyses. North American Journal of Fisheries Management 3 (1): 81-85. DOI: $10.1577 / 1548-8659(1983) 3<81$ :EOGLFS $>2.0 . C O ; 2$

Manko P. 2016. Stomach content analysis in freshwater fish feeding ecology. Vydavatel'stvo Prešovskej univerzity, Prešov, Czech Republic.

Meehan W.R., Miller R.A. 1978. Stomach flushing: Effectiveness and influence on survival and condition of juvenile salmonids. Journal of the Fisheries Research Board of Canada 35 (10): 1359-1363.

DOI: 10.1139/f78-212

Petridis D., O'Hara K. 1988. Assessment of diet in two cyprinids using a modified stomach-flushing technique. Aquaculture and Fisheries Management 19 (1): 63-68.

DOI: $10.1111 /$ j.1365-2109.1988.tb00334.x
Rosa R.S., Lima F.C.T. 2008. Peixes. [Fishes.] Pp. 8-287. In: Machado A.B.M., Drummond G.M., Paglia A.P. (eds.) Livro vermelho da fauna brasileira ameaçada de extinção. [Red book of Brazilian fauna threatened with extinction.] Ministério do Meio Ambiente, Brasília, Brazil. [In Portuguese.]

Russell W.M.S., Burch R.L. 1959. The principles of humane experimental technique. Methuen, London, UK.

Shuman D.A., Peters E.J. 2007. Evaluation of pulsed gastric lavage on the survival of captive shovelnose sturgeon. Journal of Applied Ichthyology 23 (4): 521524.

DOI: 10.1111/j.1439-0426.2007.00887.x

Vari R.P., Malabarba L.R. 1998. Neotropical ichthyology: An overview. Pp. 1-11. In: Malabarba L.R., Reis R.E., Vari R.P., Lucena Z.M.S., Lucena C.A.S. (eds.) Phylogeny and classification of Neotropical fishes. EdiPUCRS, Porto Alegre, Brazil.

Wanner G.A. 2006. Evaluation of a gastric lavage method on juvenile pallid sturgeon. North American Journal of Fisheries Management 26 (3): 587-591.

DOI: $10.1577 / \mathrm{M} 05-090.1$

Waters D.S., Kwak T.J., Arnott J.B., Pine W.E.III 2004. Evaluation of stomach tubes and gastric lavage for sampling diets from blue catfish and flathead catfish. North American Journal of Fisheries Management 24 (1): 258-261. DOI: $10.1577 / \mathrm{M} 02-156$

White H.C. 1930. Some observations on the eastern brook trout ( $S$. fontinalis) of Prince Edward Island. Transactions of the American Fisheries Society 60 (1): 101-108.

DOI: 10.1577/1548-8659(1930)60[101:SOOTEB]2.0.CO;2

Received: 29 September 2016 Accepted: 4 February 2017 Published electronically: 31 March 2017 